\title{
FEMALE ATHLETE TRIAD PADA ATLET PUTRI DI PUSAT PENDIDIKAN LATIHAN (PUSDIKLAT) RAGUNAN JAKARTA
}

\author{
Gita Ayu Rosalinda Ratu Saputri, Fillah Fithra Dieny ${ }^{*}$ \\ Program Studi Ilmu Gizi Fakultas Kedokteran Universitas Diponegoro \\ Jl.Dr.Sutomo No.14, Semarang, Telp (024) 8453708, Email : gizifk@undip.ac.id
}

\begin{abstract}
Background: Female athletes tend to consume improper for supporting their performance, so that can impact eating disorder. Eating disorder can lead menstrual irregularity and osteoporosis for them, so they have risk of female athlete triad. The aimed of this study to determine prevalence of female athlete triad in education and training centre (PUSDIKLAT) Ragunan Jakarta.

Methods: Descriptive research with cross sectional design, and calculation of total subject used stratified proportional random sampling. The sample was composed of 65 female athletes in Education and Training Center (PUSDIKLAT) Ragunan Jakarta. Data include nutritional status, eating disorder, menstrual disorder, and bone density. Assessment of nutritional status used BMI/A percentile and percent body fat; measurement of percent body fat used body fat analyzer HBF 200; assessment of eating disorder used eating disorder diagnostic scale; measurement of menstrual irregularity used questionnaire including frequency, menstrual cycle, menarche, and menstruation on last 3 months; and measurement of bone density used quantitative ultrasound bone densitometry.

Result: Female athlete triad not found on subjects, but 15 subjects $(23.1 \%)$ had bulimia and 1 subject $(1.5 \%)$ had menstrual irregularity, i.e oligoamenorrhea, whereas bone density of all subjects (100\%) normal, so that only 1 subject (1.5\%) had two symptom of female athlete triad (bulimia and oligoamenorrhea).fifty six subjects (86,2\%) had normal nutritional status. Based on fat body percent, that was found 1 subject (1.5\%) having underfat, 10 subjects (15.4\%) overfat, and 2 subjects $(3.1 \%)$ obese.

Conclusion:Female athlete triad not found in Education and Training Center (PUSDIKLAT) Ragunan Jakarta.
\end{abstract}

Keywords: Female athlete triad; eating disorder; menstrual irregularity; osteoporosis

\begin{abstract}
ABSTRAK
Latar Belakang : Atlet putri cenderung melakukan diet yang tidak tepat untuk menunjang penampilan mereka pada saat bertanding sehingga dapat mengakibatkan penyimpangan perilaku makan. Penyimpangan perilaku makan dapat menyebabkan gangguan menstruasi dan osteoporosis pada atlet tersebut sehingga atlet putri berisiko mengalami female athlete triad. Tujuan penelitian untuk mengetahui prevalensi female athlete triad yang berada di PUSDIKLAT Ragunan Jakarta.

Metode : Penelitian deskriptif dengan pendekatan cross sectional, perhitungan jumlah sampel pada penelitian ini menggunakan stratified proportional random sampling. Jumlah sampel pada penelitian ini adalah 65 atlet putri yang berada di PUSDIKLAT Ragunan Jakarta. Penilaian status gizi menggunakan persentil IMT/U dan persen lemak tubuh, pengukuran persen lemak tubuh menggunakan body fat analyzer HBF 200, penilaian penyimpangan perilaku makan menggunakan eating disorder diagnostic scale, gangguan menstruasi dinilai berdasarkan kuisioner yang meliputi frekuensi menstruasi, siklus menstruasi, usia awal menstruasi, dan mengalami haid selama 3 bulan terakhir sedangkan untuk mengukur kepadatan tulang menggunakan quantitative ultrasound bone densitometry.

Hasil : Kejadian female athlete triad tidak ditemukan pada subjek yang berada di PUSDIKLAT Ragunan Jakarta, namun 15 subjek (23.1\%) mengalami bulimia dan 1 subjek (1.5\%) mengalami gangguan menstruasi jenis oligoamenorrhea sedangkan kepadatan tulang seluruh subjek (100\%) masuk dalam kategori normal sehingga hanya satu subjek (1.5\%) yang mengalami kedua gejala female athlete triad (bulimia dan oligoamenorrhea). Lima puluh enam subjek (86.2\%) berstatus gizi normal sedangkan berdasarkan persen lemak tubuh ditemukan 1 subjek (1.5\%) underfat, 10 subjek (15.4\%) overfat dan 2 (3.1\%) atlet obesitas.
\end{abstract}

Simpulan :Kejadian female athlete triad tidak ditemukan di PUSDIKLAT Ragunan Jakarta.

Kata kunci : Female athlete triad; penyimpangan perilaku makan; gangguan menstruasi; osteoporosis

\section{PENDAHULUAN}

Atlet adalah individu yang berprofesi sebagai olahragawan atau individu yang secara umum melakukan olahraga. Atlet putri membutuhkan asupan energi, karbohidrat, protein, lemak, vitamin dan mineral yang cukup, apabila seorang atlet putri kekurangan energi dan lemak hal ini akan mempengaruhi hormon reproduksinya, kekurangan 
hormon reproduksi pada atlet putri dapat mengakibatkan amenorrhea, tidak hanya itu dalam jangka waktu yang panjang atlet putri juga dapat mengalami osteoporosis karena hormon reproduksi terutama esterogen berpengaruh pada pembentukan dan pembongkaran tulang.

Female athlete triad merupakan kombinasi dari 3 kondisi yang saling berkaitan yaitu penyimpangan perilaku makan, gangguan menstruasi, dan osteoporosis. Female athlete triad sering dialami oleh remaja putri terutama yang berprofesi sebagai atlet. $^{2}$

Penyimpangan perilaku makan, gangguan menstruasi, dan osteoporosis saling memiliki hubungan dan keterkaitan antara satu dengan lainnya. Apabila seorang atlet mengalami penyimpangan perilaku makan, hal ini akan mempengaruhi asupan energi. Kurangnya asupan energi menyebabkan menurunnya frekuensi dorongan hormon lutein yang berfungsi sebagai pemicu ovulasi. ${ }^{3}$ Amenorrhea merupakan hasil dari respon adaptasi tubuh untuk menghemat penggunaan energi. Rendahnya jumlah leptin selama membatasi asupan kalori mungkin dapat menekan hipotalamus untuk mengeluarkan gonadotropin releasing hormon $(\mathrm{GnRH}){ }^{4}$ Konsekuensi yang harus diterima oleh atlet yang mengalami amenorrhea adalah gangguan fungsi dari hipotalamus dan pituitari yang menyebabkan menurunnya produksi hormon esterogen. Hormon esterogen memiliki peran yang besar untuk menjaga kekuatan kepadatan mineral tulang, dan rendahnya esterogen berhubungan dengan rendahnya kepadatan mineral tulang dan meningkatkan risiko osteoporosis. ${ }^{5}$

Penyimpangan perilaku makan sebagian besar dialami oleh atlet putri hal ini dikarenakan untuk membentuk tubuh yang ideal tidak cukup dengan melakukan latihan fisik tetapi juga dengan melakukan diet yang berbahaya untuk mencapai tujuannya. ${ }^{6}$ Diet yang berbahaya yang dilakukan atlet putri yang menyebakan mereka mengalami penyimpangan perilaku makan seperti anoreksia dan bulimia. ${ }^{7}$ Menurut penelitian di SMA Ragunan Jakarta diketahui $1,2 \%$ atlet putri mengalami anoreksia nervosa, 4,9\% mengalami bulimia nervosa, dan 43,9\% mengalami Eating Disorder Not Otherwise Spesified (EDNOS).$^{8}$ Penelitian lain di Milwaukee menunjukkan $36 \%$ atlet tidak mengalami penyimpangan perilaku makan hanya saja ketersediaan energi didalam tubuh mereka yang termasuk dalam kategori rendah $(\leq 45$ $\mathrm{kcal} / \mathrm{kg} / \mathrm{LBM}$ ), Amenorrhea berhubungan dengan ketersediaan energi didalam tubuh dalam kategori rendah $\quad(\leq 30 \quad \mathrm{kcal} / \mathrm{kg} / \mathrm{LBM}) .{ }^{9} \quad$ Penyimpangan perilaku makan tidak hanya dilakukan oleh atlet putri tetapi dilakukan oleh remaja putri. Penelitian di SMA 70 Jakarta menunjukan 11,8\% remaja putri mengalami anoreksia nervosa, $23 \%$ mengalami bulimia nervosa, 5\% mengalami binge eating disorder, dan 48,5\% mengalami eating disorder not otherwise spesified (EDNOS). ${ }^{10}$ Penelitian di Milwaukee menunjukan $4 \%$ remaja putri memiliki ketersediaan energi yang rendah $(<$ $30 \mathrm{kcal} / \mathrm{kg} / \mathrm{LBM})^{9}{ }^{9}$

Gangguan menstruasi pada atlet putri dapat disebabkan oleh meningkatnya latihan fisik dan rendahnya asupan zat gizi yang dapat menyebabkan perubahan fisiologi dalam kontrol endokrin pada sistem menstruasi yang akhirnya menyebabkan atlet amenorrhea. ${ }^{5}$ Menurut penelitian di Edirne,Turki 9,8\% atlet mengalami amenorrhea, $0,9 \%$ atlet senam ritmik mengalami amenorrhea primer, dan 19,2\% mengalami iregulasi menstruasi. ${ }^{11}$ Penelitian lain di California menyebutkan $16,1 \%$ atlet putri mengalami oligoamenorrhea dan $6,06 \%$ atlet mengalami amenorrhea sekunder. ${ }^{12}$ Gangguan menstruasi juga dialami oleh remaja putri. Penelitian di Milwaukee menunjukan $15 \%$ remaja putri mengalami secondary amenorrhea dan $5 \%$ mengalami oligoamenorrhea. ${ }^{9}$

Tipe dan durasi dari gangguan menstruasi, rendahnya persen lemak tubuh, ketidakcukupan asupan zat gizi, perubahan berat badan, dan menurunnya jumlah plasma esterogen pada wanita berhubungan langsung dengan perubahan kepadatan tulang. ${ }^{13}$ Jumlah plasma esterogen yang rendah pada wanita dapat menyebabkan berkurangnya kepadatan tulang secara cepat, baik karena rendahnya pembentukan tulang maupun tingginya pembongkaran tulang. ${ }^{13}$ Hasil penelitian di Swedia menunjukan $10 \%$ pelari perempuan mengalami osteoporosis dan $50 \%$ mengalami osteopenia. ${ }^{2}$ Penelitian di Edirne,Turki 33,3\% atlet putri mengalami osteoporosis dan $66,7 \%$ mengalami osteopenia. ${ }^{9}$ Penelitian di Brazil 15,4\% atlet renang memiliki Bone Mineral Density (BMD) yang rendah. ${ }^{14}$

Penilitian di Edirne,Turki mengemukakan $1,36 \%$ atlet putri mengalami female athlete triad. ${ }^{11}$ Penelitian lain di Brazil mengemukakan 1,3\% atlet renang putri mengalami female athlete triad. ${ }^{14}$ Penelitian di Milwaukee 1,2\% atlet mengalami tiga kondisi (penyimpangan perilaku makan, gangguan menstruasi, dan osteoporosis) tersebut secara bersamaan. ${ }^{9}$ Female athlete triad juga ditemukan pada remaja putri yang bukan atlet. Penelitian di 
Milwaukee menunjukan $1,2 \%$ remaja putri mengalami female athlete triad. $^{9}$ Sedangkan prevalensi female athlete triad di Indonesia sampai saat ini belum diketahui.

Berdasarkan latar belakang tersebut maka penelitian dilakukan untuk mengetahui prevalensi female athlete triad pada atlet putri di pusat pendidikan dan latihan nasional Ragunan Jakarta.

\section{METODE PENELITIAN}

Penelitian ini dilakukan di Pusat Pendidikan dan Latihan (PUSDIKLAT) Ragunan Jakarta pada bulan Mei 2012. Penelitian ini merupakan penelitian deskriptif dengan pendekatan cross sectional termasuk ruang lingkup ilmu gizi masyarakat. Subjek penelitian ini adalah 65 atlet putri yang terbagi dalam beberapa cabang olahraga, yaitu cabang olahraga basket, voli, atletik, taekwondo, pencak silat, senam, tenis lapangan, tenis meja, panahan, renang, dan bulu tangkis. ${ }^{15,16,17}$ Pengambilan subjek menggunakan propotional stratified random sampling. Kriteria inklusi dalam penelitian ini adalah atlet putri yang berusia 16 - 20 tahun yang masih tercatat sebagai atlet di Pusat Pendidikan dan Latihan (PUSDIKLAT) Ragunan Jakarta yang berasal dari cabang olahraga basket, voli, atletik, taekwondo, pencak silat, senam, tenis lapangan, tenis meja, panahan, renang, dan bulu tangkis, bersedia menjadi responden, dan kooperatif.

Penelitian ini menggambarkan mengenai penyimpangan perilaku makan, gangguan menstruasi dan osteoporosis. Penilaian mengenai penyimpangan perilaku makan menggunakan eating disorder diagnostic scale. Penilaian penyimpangan perilaku makan dengan menggunakan eating disorder diagnostic scale dapat dikategorikan seperti anoreksia, bulimia, binge eating disorder, dan eating disorder not otherwise spesified. Pengkategorian penyimpangan perilaku makan didasarkan pada nilai yang ada dalam kuisioner tersebut. Penilaian untuk pengkategorian penyimpangan perilaku makan adalah kategori anoreksia meliputi menjawab 4 atau lebih pada pertanyaan nomor 2 , menjawab 4 atau lebih pada pertanyaan nomor 3 dan 4, memiliki IMT $<17,5 \mathrm{~kg} / \mathrm{m}^{2}$, menjawab 3 atau lebih pada pertanyaan nomor 21. Kategori bulimia meliputi menjawab ya pada pertanyaan nomor 5 dan 6 atau menjawab 2 atau lebih pada pertanyaan nomor 8 , menjawab 4 atau lebih pada pertanyaan nomor 3 dan 4, menjawab 1 atau lebih pada salah satu pertanyaan 15-18. Kategori binge eating disorder meliputi menjawab ya pada pertanyaan nomer 5 dan 6 atau menjawab lebih dari 2 pada pertanyaan nomer 7 , menjawab ya pada 3 pertanyaan atau lebih pada nomor 9-13, menjawab ya pada pertanyaan nomor 14 , tidak melakukan perilaku kompensasi menjawab 0 pada pertanyaan nomer 15-18, jika responden memenuhi kriteria binge eating disorder tetapi mengalami perilaku kompensasi, maka digolongkan ke dalam bulimia. Kategori eating disorder not otherwise specified (EDNOS), apabila memiliki salah satu kriteria diatas tetapi tidak termasuk dalam anoreksia, bulimia, dan binge eating disorder.

Penilaian gangguan menstruasi menggunakan kuisioner. Pertanyaan didalam kuisioner tersebut meliputi usia pertama mengalami menstruasi, frekuensi mengalami menstruasi, dan siklus menstruasi. Pengkategorian gangguan menstruasi sebagai berikut normal apabila subjek mengalami haid 10-13 kali dalam setahun dan siklus menstruasi antara 21-35 hari. Primary amenorrhea apabila tidak mengalami menstruasi sampai usia 16 tahun atau sex sekunder tidak berkembang sampai usia 14 tahun. Secondary Amenorrhea apabila subjek tidak mengalami menstruasi selama 3 bulan atau lebih setelah mengalami menstruasi pertama kali. Oligoamenorrhea apabila siklus menstruasi subjek < 21 hari atau $>35$ hari.

Penilaian osteoporosis menggunakan quantitative ultrasound bone densitometry sonost 3000. Pengkategorian kepadatan tulang subjek sebagai berikut normal apabila $T$-score $-1 \leq \mathrm{SD}<$ 2,5. Osteopenia apabila $T$-score $-2,5 \mathrm{SD}<-1$. Osteoporosis apabila $T$-score $<-2,5$.

Pengukuran status gizi subjek menggunakan IMT/U yang dikonversikan menggunakan grafik persentil CDC berdasarkan usia dan jenis kelamin dan persen lemak tubuh yang dikonversikan menggunakan grafik persen lemak tubuh Mc Carthy berdasarkan usia dan jenis kelamin. Pengukuran berat badan dan persen lemak tubuh menggunakan Body Fat Analyzer Omron seri HBF 200 dan tinggi badan menggunakan microtoice 200 $\mathrm{cm}$ dengan ketelitian $0,1 \mathrm{~cm}$.

Penilaian mengenai female athlete triad dilakukan berdasarkan hasil yang diperoleh dari penyimpangan perilaku makan, gangguan menstruasi dan osteoporosis. Pengakategorian female athlete triad yaitu apabila atlet mengalami penyimpangan perilaku makan saja, mengalami penyimpangan perilaku makan dan gangguan menstruasi, mengalami penyimpangan perilaku makan, gangguan menstruasi dan osteopenia atau osteoporosis. 
Data yang disajikan pada penelitian ini meliputi data frekuensi kategori status gizi subjek baik berdasarkan persentil IMT/U maupun berdasarkan persen lemak tubuh, frekuensi kategori durasi olahraga, frekuensi kategori penyimpangan perilaku makan, frekuensi subjek yang mengalami bulimia berdasarkan cabang olahraga, frekuensi mengenai status menstruasi, frekuensi kategori kepadatan tulang serta frekuensi
T-score berdasarkan cabang olahraga, dan frekuensi kategori female athlete triad.

\section{HASIL PENELITIAN \\ Karakteristik Subjek}

Subjek pada penelitian ini adalah 65 atlet putri dari beberapa cabang olahraga yang berada di PUSDIKLAT Ragunan Jakarta.

Tabel.1 Karakteristik Subjek

\begin{tabular}{lccc}
\hline \multicolumn{1}{c}{ Karakteristik Subjek } & Minimum & Maksimum & Rerata (SB) \\
\hline Usia (Tahun) & 16 & 18 & $16.42(\mathrm{SB}$ \\
& & & $0.610)$ \\
Berat Badan (Kg) & 41.3 & 82.9 & $56.95(\mathrm{SB}$ \\
& & & $9.749)$ \\
Tinggi Badan (cm) & 144 & 177 & $161.3(\mathrm{SB}$ \\
& & & $6.745)$ \\
Persentil IMT/U (Percentil) & 14.5 & 99.2 & $58.48(\mathrm{SB}$ \\
& & & $23.894)$ \\
Persen Lemak Tubuh (\%) & 9.8 & 38.6 & $26.0(\mathrm{SB} 5.089)$ \\
\hline
\end{tabular}

\section{Status Gizi}

Hasil pengukuran persentil IMT/U didapat dikategorikan maka dapat dilihat dalam tabel.2 berikut. hasil sebesar $58.48 \pm 23.89$, jika persentil tersebut

Tabel.2 Kategori Status Gizi Subjek Berdasarkan Persentil IMT/U

\begin{tabular}{lcc}
\hline \multicolumn{1}{c}{ Kategori } & $\mathrm{n}$ & $\%$ \\
\hline Normal & 56 & 86.2 \\
Kelebihan berat badan & 8 & 12.3 \\
Obesitas & 1 & 1.5 \\
\hline Total & 65 & 100 \\
\hline
\end{tabular}

Tabel.2 menunjukan bahwa $56(86.2 \%)$ subjek berstatus gizi normal, 8 (12.3\%) subjek kelebihan berat badan dan 1 (1.5\%) subjek obesitas. Subjek yang mengalami berat badan berlebih adalah 5 atlet voli dan 3 atlet basket serta yang mengalami obesitas adalah 1 atlet atletik (lempar martil).

Hasil pengukuran persen lemak tubuh didapatkan rerata sebesar $26 \pm 5.1 \%$. Jika rerata tersebut dikategorikan maka hasil dapat dilihat pada tabel. 3 berikut.

Tabel.3 Kategori Status Gizi Subjek Berdasarkan Persen Lemak Tubuh

\begin{tabular}{lcc}
\hline \multicolumn{1}{c}{ Kategori } & $\mathrm{n}$ & $\%$ \\
\hline Normal & 52 & 80 \\
Underfat & 1 & 1.5 \\
Overfat & 10 & 15.4 \\
Obesitas & 2 & 3.1 \\
\hline Total & 65 & 100 \\
\hline
\end{tabular}

Tabel.3 menunjukan $52 \quad(80 \%)$ subjek normal, $1(1.5 \%)$ subjek underfat, 10 (15.4\%) subjek overfat dan $2(3.1 \%)$ subjek obesitas. Underfat dialami oleh 1 atlet senam sedangkan overfat dialami oleh 4 atlet voli, 3 atlet basket, 1 atlet panahan, 1 atlet tenis meja, dan 1 atlet taekwondo, Obesitas dialami oleh 1 atlet atletik (lempar martil) dan 1 atlet voli. 
Penyimpangan Perilaku Makan
Jenis penyimpangan perilaku makan meliputi anoreksia, bulimia, binge eating disorder, dan eating disorder not otherwise specified.

Tabel.4 Kategori Penyimpangan Perilaku Makan Subjek

\begin{tabular}{lcc}
\hline \multicolumn{1}{c}{ Kategori } & $\mathrm{n}$ & $\%$ \\
\hline Normal & 50 & 76.9 \\
Bulimia & 15 & 23.1 \\
\hline Total & 65 & 100 \\
\hline
\end{tabular}

Tabel.4 menyatakan hasil bahwa $15(23.1 \%)$ subjek mengalami bulimia. Bulimia dialami oleh 6 $(40 \%)$ atlet voli, $2(13.3 \%)$ atlet basket, $1(6.7 \%)$ atlet senam, $1(6.7 \%)$ atlet renang, dan $5(33.3 \%)$ atlet beladiri.

\section{Status Menstruasi}

Rerata usia awal menstruasi (menarche) pada seluruh subjek adalah $12.75 \pm 1.3$ tahun tahun dengan nilai minimum 8 tahun dan nilai maksimum 15 tahun.

Tabel.5 Status Menstruasi

\begin{tabular}{|c|c|c|}
\hline Kategori & $\mathrm{n}$ & $\%$ \\
\hline \multicolumn{3}{|l|}{ Usia awal menstruasi } \\
\hline$<16$ tahun & 65 & 100 \\
\hline$>16$ tahun & 0 & 0 \\
\hline \multicolumn{3}{|c|}{$\begin{array}{l}\text { Mengalami menstruasi } 3 \text { bulan } \\
\text { terakhir }\end{array}$} \\
\hline Ya & 65 & 100 \\
\hline Tidak & 0 & 0 \\
\hline \multicolumn{3}{|l|}{ Frekuensi menstruasi } \\
\hline$<10 \mathrm{kali} /$ tahun & 0 & 0 \\
\hline 10-13 kali /tahun & 65 & 100 \\
\hline \multicolumn{3}{|l|}{ Siklus menstruasi } \\
\hline$<21$ hari & 0 & 0 \\
\hline 21-35 hari & 64 & 98.5 \\
\hline$>35$ hari & 1 & 1.5 \\
\hline \multicolumn{3}{|l|}{ Gangguan Menstruasi } \\
\hline $\begin{array}{l}\text { Tidak mengalami gangguan } \\
\text { menstruasi (Normal) }\end{array}$ & 64 & 98.5 \\
\hline Primarry Amenorrhea & 0 & 0 \\
\hline Secondary Amenorrhea & 0 & 0 \\
\hline Oligoamenorrhea & 1 & 1.5 \\
\hline
\end{tabular}

Seluruh subjek $(100 \%)$ mengalami menstruasi pertama pada usia kurang dari 16 tahun sehingga tidak ditemukan risiko primarry amenorrhea. Seluruh subjek (100\%) mengalami haid selama 3 bulan terakhir sehingga tidak ditemukan risiko terjadinya secondarry amenorrhea pada subjek. Frekuensi menstruasi pada 65 subjek (100\%) 10-13 kali/ tahun. Siklus menstruasi pada 64 subjek (98.5\%) berkisar antara 21- 35 hari, dan siklus menstruasi dalam range ini masih normal namun ada $1(1.5 \%)$ subjek dengan siklus menstruasi $>35$ hari, siklus menstruasi $<21$ hari atau > 35 hari termasuk dalam kategori oligoamenorrhea. Gangguan menstruasi, oligoamenorrhea hanya dialami oleh 1 subjek (1.5\%) sedangkan 64 subjek (98.5\%) tidak mengalami gangguan menstruasi (normal). Oligoamenorrhea dialami oleh 1 atlet voli.

\section{Kepadatan Tulang}

Rerata skor kepadatan tulang pada seluruh subjek adalah 2.21 $\pm 1.41 \mathrm{SD}$ dengan nilai minimum -0.4 dan nilai tertinggi +7 . Seluruh subjek $(100 \%)$ memiliki kepadatan tulang yang normal. T-score per cabang olahraga terdapat pada tabel.6 berikut . 
Tabel.6 T-score Pada Subjek Berdasarkan Cabang Olahraga

\begin{tabular}{lcc}
\hline \multirow{2}{*}{ Cabang Olahraga } & \multicolumn{2}{c}{ T-score } \\
\cline { 2 - 3 } & Minimum & Maksimum \\
\hline Voli & +0.3 & +4 \\
Basket & +0.6 & +6 \\
Bulutangkis & +2 & +4 \\
Panahan & 0 & 0 \\
Atletik & 0 & +7 \\
Senam & +0.1 & +4 \\
Renang & -0.4 & +1.6 \\
Tenis & -0.3 & +2.3 \\
Beladiri & +1.4 & +4 \\
\hline
\end{tabular}

Skor kepadatan tulang pada atlet voli, basket, bulutangkis, beladiri, atletik cenderung tinggi sedangkan skor kepadatan tulang atlet renang dan tenis meja lebih rendah dibanding atlet cabang olahraga lainnya.

\section{Female Athlete Triad}

Female athlete triad tidak dialami oleh subjek pada penelitian ini namun ditemukan
$15(23.1 \%)$ subjek yang mengalami penyimpangan perilaku makan jenis bulimia, 1(1.5\%) subjek mengalami gangguan menstruasi jenis oligoamenorrhea dan 1(1.5\%) mengalami bulimia dan oligoamenorrhea. Subjek yang mengalami bulimia dan oligoamenorrhea ini adalah atlet voli.

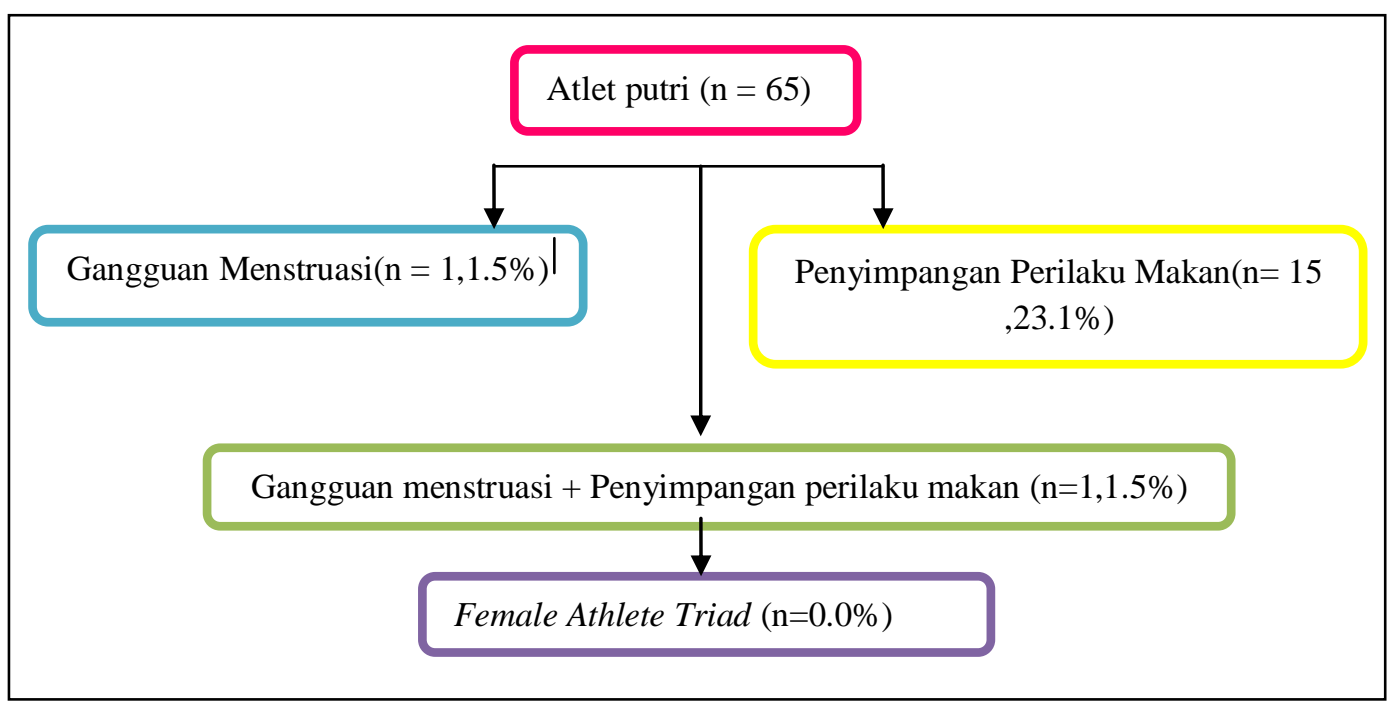

Gambar.1 Prevalensi Gangguan Menstruasi, Penyimpangan Perilaku Makan, dan Female Athlete Triad *gangguan menstruasi (oligoamenorrhea), penyimpangan perilaku makan(bulimia), female athlete triad (penyimpangan perilaku makan, gangguan menstruasi, dan osteoporosis)

\section{PEMBAHASAN}

\section{Status Gizi}

Status gizi pada subjek penelitian ini berdasarkan persentil IMT/U ditemukan 56 $(86.2 \%)$ subjek berstatus gizi normal, $8(12.3 \%)$ subjek kelebihan berat badan serta $1(1.5 \%)$ subjek mengalami obesitas. Sedangkan status gizi subjek berdasarkan persen lemak tubuh ditemukan 52 $(80 \%)$ subjek berstatus gizi normal. $1(1.5 \%)$ subjek masuk dalam kategori underfat, 10 (15.4\%) subjek masuk dalam kategori overfat dan 2 (3.1\%) subjek masuk dalam kategori obesitas. Status gizi subjek yang mengalami penyimpangan perilaku makan dalam kategori normal dan ada beberapa yang kelebihan berat badan. Atlet yang berstatus gizi kelebihan berat badan dan obesitas dikarenakan tuntutan dari olahraga yang dijalani. Berdasarkan persentil IMT/U ditemukan 1 atlet yang berstatus gizi normal tetapi saat dilihat komposisi tubuhnya atlet tersebut masuk dalam 
kategori underfat, sedangkan ada beberapa atlet yang berdasarkan IMT/U dan persen lemak tubuhnya termasuk dalam kategori obesitas, dengan status gizi yang demikian status menstruasi dan kepadatan tulang subjek dalam kategori normal. Menurut penelitian pada atlet, IMT dan persen lemak tubuh tidak berpengaruh secara signifikan terhadap status menstruasi, sedangkan pada kepadatan tulang atlet keduanya memiliki pengaruh yang signifikan. ${ }^{18,19}$

\section{Penyimpangan Perilaku Makan}

Hasil penelitian ditemukan $50(76.9 \%)$ atlet tidak mengalami penyimpangan perilaku makan (normal), namun ada 15 (23.1\%) atlet mengalami bulimia. Bulimia dialami oleh 6 atlet voli, 2 atlet basket, 1 atlet renang, 1 atlet senam, 3 atlet taekwondo, dan 2 atlet pencak silat. Penelitian sebelumnya di PUSDIKLAT Ragunan Jakarta menunjukan $41 \quad(50 \%)$ atlet tidak mengalami penyimpangan perilaku makan, namun $1(1,2 \%)$ atlet mengalami anoreksia, $4(4,9 \%)$ atlet mengalami bulimia dan $36 \quad(49,9 \%)$ atlet mengalami eating disorder not otherwise specified (EDNOS). Penelitian sebelumnya diperoleh hasil sebagai berikut anoreksia dialami oleh 1 atlet voli, bulimia dialami oleh 1 atlet senam, 1 atlet atletik, 1 atlet voli, 1 atlet basket, EDNOS dialami oleh 4 atlet senam, 4 atlet atletik, 2 atlet renang, 14 atlet voli, 1 atlet basket, 5 atlet tenis, 1 atlet angkat besi, 5 atlet beladiri. ${ }^{8}$

Banyaknya subjek yang tidak mengalami penyimpangan perilaku makan disebabkan pengaturan makan yang baik,tetapi masih ada atlet yang kurang patuh dalam menjalani diet yang ditentukan, menyebabkan atlet melakukan diet yang salah, salah satunya adalah penyimpangan perilaku makan. Penyimpangan perilaku makan dipengaruhi oleh beberapa faktor antara lain faktor personal/psikologi, keluarga, media, dan lingkungan sosial. ${ }^{21}$

Penyimpangan perilaku makan merupakan spektrum dari sikap dan kebiasaan makan yang tidak normal. ${ }^{7}$ Penyimpangan perilaku makan rentan terjadi pada masa remaja dan dewasa awal yaitu antara usia 13 sampai 18 tahun. ${ }^{20}$ Rerata usia subjek pada penelitian ini 16.42 (SB 0.610) tahun dengan rentang usia 16-18 tahun. Usia subjek yang tergolong masih remaja sangat rentan mengalami penyimpangan perilaku makan. ${ }^{21}$ Atlet yang mengalami bulimia merasa tubuhnya kurang ideal, merasa takut apabila berat badannya naik karena apabila berat badannya naik akan mempengaruhi performa mereka di lapangan. Atlet taekwondo dan pencak silat cenderung menjaga berat badannya karena ketentuan pertandingan yang mengharuskan berat badan mereka tetap stabil. Atlet renang dan senam cenderung menjaga berat badannya karena bentuk tubuh menjadi salah satu penilaian ketika bertanding. Atlet putri dan pelatihnya, berfikir atlet yang ramping memiliki performa yang lebih baik pada saat pertandingan dan terlihat lebih indah ketika mengunakan seragam atau kostum yang telah disediakan. Pada olahraga yang menggunakan seragam, tubuh atlet menjadi sorotan para juri. ${ }^{22,23}$ atlet voli dan basket yang mengalami bulimia berstatus gizi kelebihan berat badan, menurut penelitian atlet yang mengalami kelebihan berat badan cenderung mengalami penyimpangan perilaku makan. ${ }^{18}$

Atlet yang mengalami bulimia akan makan dengan jumlah dan jenis yang tidak terkontrol setelah mereka bertanding, setelah mereka makan dengan jumlah yang tidak terkontrol mereka cenderung melakukan olahraga tambahan dan melewatkan waktu makan saat makan siang atau makan malam sebagai perilaku kompensasi. Olahraga yang dilakukan adalah lari dengan menggunakan pakaian sauna selama 60 menit, dan melakukan sit-up, push-up, back-up masingmasing sebanyak 100 kali, olahraga ini dilakukan 4-6 kali per minggu.

\section{Gangguan Menstruasi}

Gangguan menstruasi hanya dialami oleh $1(1.5 \%)$ atlet voli, atlet tersebut mengalami oligoamenorrhea, siklus haid yang dialami lebih dari 35 hari. Gangguan menstruasi ini dapat disebabkan beberapa faktor, salah satunya peningkatan beban latihan secara tiba-tiba. ${ }^{24}$ Gangguan menstruasi pada atlet putri dapat disebabkan oleh meningkatnya latihan fisik yang dapat menyebabkan perubahan fisiologi dalam kontrol endokrin pada sistem menstruasi yang akhirnya menyebabkan atlet amenorrhea. ${ }^{5}$ Peningkatan beban latihan secara tiba-tiba dialami oleh atlet ini karena sebelumnya atlet tersebut latihan di pusat pelatihan daerah sedangkan sekarang latihan di pusat pendidikan dan latihan ragunan, beban latihan yang lebih berat dan durasi latihan yang lebih lama dari tempat yang sebelumnya. Adanya perbedaan frekuensi, durasi, dan intesitas latihan dari tempat yang lama dengan tempat yang baru yang memicu terjadinya gangguan menstruasi ini.

\section{Osteoporosis}

Osteoporosis tidak dialami oleh atlet yang menjadi subjek penelitian, hasil penelitian menunjukan $65(100 \%)$ atlet memiliki tulang yang normal. Range $T$-score berkisar antara -0.4 sampai 
+7. Kepadatan tulang adalah hasil dari proses dinamis dari pembentukan tulang dan pembongkaran tulang yang disebut bone remodelling. ${ }^{25}$ Kepadatan dan kekuatan tulang pada atlet lebih tinggi dari yang bukan atlet. ${ }^{26}$ Kepadatan tulang subjek yang termasuk dalam kategori normal dengan nilai $T$-score yang cenderung tinggi salah satunya dipengaruhi oleh aktifitas fisik yang tinggi hal ini dapat dilihat dari durasi latihan subjek yang berkisar antara 3.5 sampai 7 jam perharinya dengan frekuensi latihan 6 kali perminggu. Aktifitas fisik yang tinggi atau yang bertumpu pada berat badan dapat mempengaruhi kepadatan tulang. Osteosit berperan sebagai mekanoreseptor, merespon, dan mengeluarkan faktor kimia yang dapat mendorong prolifrasi osteoblas pada tulang. ${ }^{26}$ Aktifitas fisik yang tinggi atau menggunakan berat tubuh sebagai tumpuan dapat mempengaruhi stimulus osteogenik yang berhubungan dengan masa tulang. ${ }^{27}$

Atlet renang memiliki rata-rata nilai $T$-score yang rendah dibandingkan dengan atlet lainnya, skor kepadatan tulang pada atlet renang berkisar antara

-0.4SD sampai +1.6 SD. Hal ini berkaitan dengan olahraga yang dijalani tidak menumpu pada berat badan sehingga densitas tulang tidak meningkat. Pada beberapa penelitian disebutkan bahwa kepadatan tulang atlet renang cenderung lebih rendah daripada atlet lain yang olahraga melibatkan berat badan. ${ }^{25}$

\section{Female Athlete Triad}

Hasil penelitian yang dilakukan di PUSDIKLAT Ragunan Jakarta menunjukan, atlet yang menjadi subjek pada penelitian ini tidak ada yang mengalami 3 kategori female athlete triad. Penyimpangan perilaku makan dialami oleh 15 $(23.1 \%)$ atlet dan gangguan menstruasi dialami oleh $1(1.5 \%)$ subjek serta hanya ada $1(1.5 \%)$ atlet yang mengalami penyimpangan perilaku makan (bulimia) dan mengalami gangguan menstruasi (oligoamenorrhea). Kejadian female athlete triad memang tidak ditemukan di PUSDIKLAT Ragunan Jakarta karena risiko terjadinya female athlete triad ditempat ini tidak ada, selain itu female athlete triad merupakan masalah baru yang prevalensinya masih kecil. Penelitian di Milwaukee menunjukan hasil yang sama yaitu tidak ditemukan kejadian female athlete triad pada atlet triathlon sedangkan penelitian di Malaysia menunjukan hanya $1.9 \%$ atlet senam mengalami female athlete triad, ${ }^{28}$ dan di Turky $1.36 \%$ atlet putri yang mengalami female athlete triad. ${ }^{11}$
Faktor risiko yang memicu terjadinya female athlete triad antara lain olahraga yang memeriksakan berat badan secara rutin, terjadi isolasi sosial akibat olahraga, olahraga berlebih, tekanan harus menang, hukuman apabila terjadi kenaikan berat badan, dan tekanan dari orang tua maupun pelatih. ${ }^{29}$ Female athlete triad tidak ditemukan pada atlet yang berada di PUSDIKLAT Ragunan Jakarta karena faktor risiko tersebut tidak terjadi pada atlet.

Pengaturan makan yang baik pada atlet membuat atlet tidak merasa tertekan apabila diharuskan menurunkan berat badan karena sudah ada ahli gizi yang memperhitungkan dan menyiapkan kebutuhan atlet serta durasi latihan yang teratur sudah mampu membantu atlet mempertahankan berat badan. Perencanaan makan yang baik dalam suatu institusi akan mempengaruhi asupan makan atlet, asupan makan yang baik akan membantu atlet untuk memperoleh prestasi yang optimal. ${ }^{30}$ Isolasi sosial tidak dialami oleh atlet di PUSDIKLAT karena mereka mendapat jadwal libur dan boleh keluar asrama diakhir pekan. Tekanan dari pelatih atau orang tua bahwa mereka harus menang tidak dialami karena pelatih dan orang tua cenderung menekankan untuk memberikan penampilan terbaik.

\section{SIMPULAN}

Penelitian ini menemukan $15 \quad(23.1 \%)$ subjek mengalami bulimia dan $1(1.5 \%)$ subjek mengalami oligoamenorrhea, sehingga hanya ditemukan 1 (1.5\%) subjek yang mengalami bulimia dan oligoamenorrhea. Lima puluh enam subjek $(86.2 \%)$ berstatus gizi normal sedangkan berdasarkan persen lemak tubuh ditemukan 1 subjek (1.5\%) underfat, 10 subjek $(15.4 \%)$ overfat dan $2(3.1 \%)$ atlet obesitas.

\section{SARAN}

PUSDIKLAT merupakan pusat latihan yang sudah memperhatikan gizi untuk atlet agar dapat tampil optimal serta sudah melaksanakan pengontrolan diet yang baik untuk para atlet yang bernaung dibawahnya. Namun disisi lain masih memerlukan pengawasan yang lebih ketat dari ahli gizi agar penyimpangan perilaku makan tidak terjadi pada lebih banyak atlet.

Perlu adanya penelitian serupa di tempat latihan lain yang berada di PUSDIKLAT Ragunan Jakarta atau pada club-club olahraga lain yang tidak berbasis asrama atau pada atlet yang tidak terikat pada salah satu club serta perlu adanya 
penelitian female athlete triad pada remaja putri yang bukan atlet.

\section{DAFTAR PUSTAKA}

1. Lisa D. Krause's food and nutrition therapy: Nutrition for exercise and sports performance. Elsevier. Philadelphia,USA. 2008;22:587-603

2. Pettersson U, Stalnacke B, Ahlenius G, Henricksson-Larsen K, dan Lorentzon R. Low bone mass density at multiple skeletal sites, including the appendicular skeleton in amenorrheic runners. Calciferous Tissue International.1999;64:125-177.

3. Loucks AB. Energy Availability, Not Body Fatness, Regulated Reproductive Function in Women. Excercise in Sport Science Review. 2003;31:144-148

4. Barash IA, Cheung CC, Weigle DS, Ren H, Kabigting EB, Kuijper JL, et al. Leptin is a Metabolic signal to the Reproductive System. Endocrinology.1996;137:3144-3147

5. Karen B. Female Athlete Triad. BMJ. 2005;330:244-246

6. Jorrun S, Monica K. The Female Football Player, Disorder Eating, Menstrual Function and Bone Health. Br J Sport Med. 2007;41 (Suppl I) :i68-i72

7. Michelle T, Mitchell J, Hava S, Jeanne F. Dietary Restraint and Low Bone Mass in Female Adolescent Endurance Runners. Am J Clin Nutr. 2008;87:36-43

8. Istiqomah NP. Hubungan antara Faktor Eksternal dan internal terhadap Kecenderungan Penyimpangan Perilaku Makan pada Atlet Wanita di SMP/SMA Negeri Ragunan Jakarta (Skripsi).FKM UI.2009

9. Anne ZH, Nicholas MP, LuAnn M, Guillermo FC, Charles RW, Raymond GH, Jane ES, et al. Prevalence of the Female Athlete Triad in High School Athletes and Sedentary Students. Clin J Sport Med.2009;19(5):421-428

10. Putra WKY. Gambaran dan Faktor-Faktor yang Berhubungan dengan Kecenderungan Penyimpangan Perilaku Makan pada Siswi SMAN 70 Jakarta Selatan tahun 2008 (Skripsi).FKM UI.2008

11. Selma AV, Erdal V, Gülay DA, Cem K, Levent Ö. Prevalence of The Female Athlete Triad in Edirne Turkey. Journal of Sports and medicine.2005;4:550-555

12. Hava S, Jeanne F, Mitchel J, Michelle T, Mandra J, Susan S. Influence üSports Participation and Menarche on Bone Mineral Density of Female High School Athletes.Journal of Science and Medicine in Sport.2007;10:170-179

13. Myburgh KH, Hutchins J, Fataar AB, Hough SF, Noakes TD. Low Bone Density is an Etiologic Factor for Stress Fractures in Athletes. Ann Intern Med.1990;113:754-759
14. Annie S, Eliane AS, Fatima PO, Beatriz GR. Female Athlete Triad in Elite Swimmers of the City of Rio de Janeiro Brazil. Elsevier.2009;25:634-639

15. Snedecor GW, Cochran WG. Statistical Methods 6th ed, Ames, IA: Iowa State University Press. 1967.

16. Sudigdo S, Sofyan I. Dasar-Dasar Metodelogi Penelitian Klinis. 3rd ed. Jakarta: Sagung Seto;2008.p.327

17. Soekidjo N. Metodelogi Penelitian Kesehatan. 1st ed. Jakarta: Rineka Cipta;2005.p.87

18. Mulatni NK, Kaur $\mathrm{H}$, Chahal A. Impact of Sporting Activities on Bone Mineral Density. Patiala: Journal of Excercise Science and Physiotherapy. 2011:7(2),103-109.

19. Klentrou P, Plyley M. Onset of Puberty, Menstrual Frequency, and Body Fat in Elite Rhythmic Gymnasts Compared with Normal Control. Canada: Br J Sport Med. 2003:37,490-494

20. McComb, Jacalyn JR. Eating Disorder in Women and Children: Prevention Stress Management and Treatment. Washington. CRC press. 2001

21. Brown, Judith E. Nutrition Through the Life Cycle. 2th ed. USA: Thomson Wadsworth.2005

22. Berry T, Howe B. Risk Factor for Disorder Eating in Female University Athletes. USA : Journal of Sport Behavior. 2000:23(3),207-218

23. Thompson R, Sherman RT. Athletes, Athletic Performance, and Eating Disorder. USA: Journal of Social Issues. 1999:55(2), 317-337

24. Burke L. Sports amenorrhea, osteopenia, stress fractures and calcium. Clinical Sports Nutrition.McGraw - Hill Book Co. Sydney. 1994. Pg 200-226.

25. Dana LC, Amy LM, Debra B, Gunnar BP. Weight Bearing Exercise and Markers of Bone Turnover in Female Athletes. Ohio: Journal Applied Physiology. 2001:90,565-570.

26. Andreoli A, Monteleone M, Loan MV, Promenzio L, Tarantino U, Lorenzo A. Effects of Different Sports on BMD and Muscle Mass in Highly Trained Athletes. Official Journal of the American College of Sports Medicine. 2001:33,507-511

27. Lanyon LE. The Success and Failure of the Adaptive Response to Functional Load-Bearing in Averting Bone Fracture. Journal Bone. 1989:13,17-21

28. Quah YV, Poh BK, Ng LO, Noor MI. The Female Athlete Triad Among Elite Malaysian Athletes: Prevalence and Associated Factors. Malaysia. Asia Pacific Journal Clinical Nutrition. 2009:18(2), 200-208

29. Irianto Djoko P. Panduan gizi lengkap keluarga dan olahragawan. Yogyakarta: Penerbit Andi; 2007. P.89

30. Julie A dan Doudlas R. The Female Athlete Triad. Am Fam Physician. 2000;61(11):3357-3364 